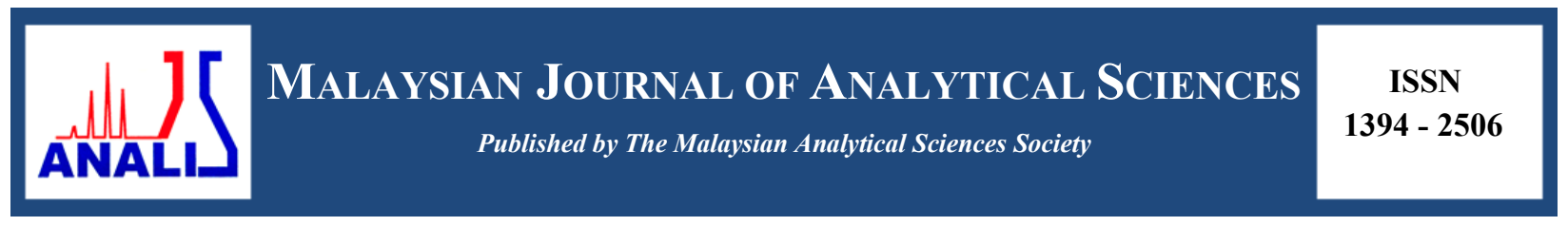

\title{
SINTESIS DAN PENCIRIAN HIDROGEL TERBIODEGRADASI BERASASKAN BAKTERIA SELULOSA MENGGUNAKAN TEKNIK RADIASI ULTRA LEMBAYUNG
}

\author{
(Synthesis and Characterization of Biodegradable Bacterial Cellulose Based Hydrogels Using \\ Ultra Violet Curable Radiation)
}

Norhanisah Jamaludin dan Azwan Mat Lazim*

Pusat Pengajian Sains Kimia dan Teknolohi Makanan, Fakulti Sains dan Teknologi,

Universiti Kebangsaan Malaysia, 43600 UKM Bangi, Selangor, Malaysia

*Corresponding author: azwanlazim@ukm.edu.my

Received: 16 January 2017; Accepted: 16 July 2017

\begin{abstract}
Abstrak
Hidrogel terbiodegradasi berasaskan selulosa bakteria (BC) daripada nata de coco dihasilkan melalui proses radiasi ultra lembayung terawat. Selulosa bakteria (BC) telah digabungkan bersama akrilamida (AM) pada nisbah yang berbeza. N,Nmetilena bisakrilamida (BIS) dan kalium persulfat (KPS) kemudiannya ditambah untuk mensintesis hidrogel dengan nisbah $5 \%$ w/v (hidrogel A) dan 10\% w/v (hidrogel B). Hidrogel berasaskan AM juga turut disintesis dengan label hidrogel pemalar. Dalam kajian ini, akrilamida (AM) bertindak sebagai monomer dan terikat pada struktur tulang belakang selulosa. Kalium persulfat (KPS) bertindak sebagai bahan pemula cahaya di mana ianya membantu dalam menghasilkan radikal bebas dan N,N-metilena bisakrilamida (BIS) pula berfungsi sebagai agen pentaut silang. Berdasarkan penggunaan teknik radiasi dan bahan pemula cahaya, tindak balas yang terlibat adalah pempolimeran radikal bebas. Lima analisis telah dilakukan bagi mencirikan hidrogel A dan $\mathrm{B}$ iaitu ujian pengembangan menggunakan lima larutan penimbal $\mathrm{pH}$, analisis struktur kimia, analisis gravimetri termal (TGA), analisis kalorimetri pengimbasan pembezaan (DSC) dan analisis pembelauan sinar-X. Morfologi permukaan bagi kedua - dua hidrogel A dan B juga telah ditentukan menggunakan analisis mikroskopi pengimbasan elektron (SEM). Hasil analisis telah menunjukkan kewujudan liang - liang terbuka dalam hidrogel A adalah lebih banyak berbanding dengan hidrogel B.
\end{abstract}

Kata kunci: hidrogel, selulosa bakteria, ultra lembayung terawat

\begin{abstract}
A rapid biodegradable hydrogel made up of bacterial cellulose (BC) from nata de coco was prepared by curing it under the ultra violet (UV) radiation. Bacterial cellulose (BC) is grafted with acrylamide (AM) at different proportions. Potassium persulphate (KPS) and N,N-methylene bisacrylamide (BIS) are added to synthesize hydrogels at the ratio of 5\% w/v (hydrogel A) and $10 \%$ w/v (hydrogel B). Acrylamide hydrogel is also synthesized as a control hydrogel. In this research, acrylamide acts as a monomer that binds itself to the cellulose backbone while potassium persulfate (KPS) as an intiator where it produces free radicals. The $\mathrm{N}, \mathrm{N}-$ methylene bisacrylamide (BIS) is used as a cross linker. Here, free radical polymerization is involved. Several analyses have been done to characterise hydrogel $\mathrm{A}$ and $\mathrm{B}$ which are swelling test in five different buffer solutions, chemical structure analysis, thermal gravimetry analysis (TGA), diffrential scanning calorimetry (DSC) and X-ray diffraction (XRD). The surface morphology for both hydrogel A and B are also determined by using scanning electron microscopy (SEM) analysis. The images found that the pores in hydrogel A were more than in hydrogel B.
\end{abstract}

Keywords: hydrogel, bacterial cellulose, curable ultra violet 


\section{Norhanisah \& Azwan: SINTESIS DAN PENCIRIAN HIDROGEL TERBIODEGRADASI BERASASKAN BAKTERIA SELULOSA MENGGUNAKAN TEKNIK RADIASI ULTRA LEMBAYUNG}

\section{Pengenalan}

Hidrogel merupakan bahan polimer yang boleh menyerap sejumlah besar air tanpa ia melarut dalamnya [1]. Hidrogel merupakan gel kimia yang distabilkan oleh jaringan paut silang secara kovalen [2]. Polimer hidrogel boleh dikategorikan kepada dua kelas iaitu sintetik dan berasaskan bahan semulajadi [3]. Sejak bermulanya kajian berkaitan hidrogel, ia telah menjadi salah satu bahan polimer yang paling banyak dikaji terutamanya dalam bidang biologi. Malah, disebabkan oleh kesedaran terhadap teknologi hijau dan bio-serasi pada masa kini, kebanyakan hidrogel diperbuat daripada sumber semulajadi dan salah satunya adalah selulosa. Penggunaan selulosa sedikit sebanyak dapat mendorong penghasilan hidrogel yang mempunyai sifat ketulenan, keseragaman dan juga kekuatan mekanikal yang tinggi [4].

Selulosa merupakan salah satu sumber semulajadi yang banyak dan mudah untuk didapati di muka bumi. Selulosa terbahagi kepada dua jenis iaitu daripada sumber bakteria dan tumbuhan [5]. Secara kimianya, selulosa bakteria (BC) adalah sama seperti selulosa tumbuhan (PC) walaupun mempunyai struktur makromolekular dan sifat fizikal yang berbeza. Selulosa dari kedua-dua sumber ini terikat pada ikatan 1,4- $\beta$-glukosidik yang menjadikan kadar penghabluran selulosa adalah tinggi dan tidak mudah larut dalam air. Walau bagaimanapun, biosintesis BC menghasilkan fiber bersaiz nano dengan magnitud dua kali ganda lebih kecil berbanding dengan fiber PC. Oleh itu, selulosa bakteria menunjukkan jaringan fiber ultra halus yang berkebolehan untuk menyerap air dengan banyak dan mempunyai daya ketegangan yang lebih tinggi daripada PC [6]. Salah satu selulosa yang biasa digunakan dalam industri makanan adalah selulosa bakteria (BC). Selulosa bakteria boleh dihasilkan daripada pelbagai sumber dan salah satu contoh BC adalah nata de coco. Nata de coco merupakan sejenis pencuci mulut berbentuk kiub gelatin dan berwarna putih. Secara asasnya, kiub gelatin tersebut diperbuat daripada air kelapa melalui proses fermentasi oleh organisma Acetobacter xylinium [6].

Oleh kerana hidrogel menawarkan pelbagai aplikasi [7], maka kajian ke atas hidrogel telah mendapat perhatian umum dan dijalankan secara meluas. Sebagi contoh, hidrogel telah digunakan sebagai medium penghantaran ubat dalam sistem tubuh manusia [8], bahan penjerap, salutan [7] dan nanoreaktor. Bagi menghasilkan suatu hidrogel yang terbaik, kaedah yang dipilih mestilah efektif bagi mengurangkan kos serta menjimatkan masa. Antara kaedah yang pernah digunakan untuk mensintesis hidrogel adalah kaedah sinaran gamma, sinaran alur elektron, gelombang mikro dan kaedah kimia [9].

Seperti yang telah diketahui, kebanyakan hidrogel yang telah dihasilkan adalah berasaskan polimer sintetik. Walaupun ia telah digunakan secara meluas, namun, polimer sintetik merupakan bahan yang tidak boleh diperbaharui dan proses penghasilannya yang rumit turut menyebabkan kos untuk menghasilkannya adalah tinggi. Malah, polimer sintetik juga merupakan bahan yang tidak mesra alam dan tidak boleh terbiodegradasi [9]. Sesetengah daripada bahan kimia yang digunakan dalam penghasilan hidrogel adalah toksik, dan jika tidak dirawat dengan sempurna ia akan menyumbang kepada pencemaran alam sekitar. Oleh yang demikian, kini kajian yang dijalankan adalah lebih bertumpu kepada penghasilan produk mudah terbiodegradasi dan mesra alam.

Memandangkan tiada kajian berkaitan penghasilan hidrogel terbiodegradasi berasaskan nata de coco dengan menggunakan teknik radiasi ultra lembayung terawat pernah dilakukan, ini merupakan satu peluang yang baik untuk meneroka dan mengkaji teknik tersebut. Ini kerana kaedah ini menawarkan satu teknik yang mudah, boleh alih dan kos efektif berbanding kaedah radiasi gamma, alur elektron serta gelombang mikro yang memerlukan tempat khas dan mahal. Oleh itu, kajian ini dilakukan bertujuan untuk mensintesis hidrogel berasaskan selulosa bakteria dengan menggunakan teknik radiasi ultra lembayung terawat. Hidrogel yang dibangunkan menggunakan teknik ini kemudiannya akan dianalisa serta dicirikan terhadap hidrogel dengan menggunakan ujian pengembangan, analisis spektroskopi inframerah transformasi Fourier (ATR-FTIR), kalorimetri pengimbasan pembezaan (DSC), analisis gravimetri termal (TGA), pembelauan sinar-X (XRD) dan mikroskopi pengimbasan elektron (SEM). Hasil kajian diharapkan akan menjadi kaedah alternatif bagi membangunkan hidrogel dan digunakan dengan lebih meluas.

\section{Bahan dan Kaedah}

\section{Bahan}

Selulosa bakteria yang disediakan daripada nata de coco (diperoleh dari industri makanan Kuala Selangor, Malaysia) yang telah ditulenkan dan dikisar. Bahan kimia seperti akrilamida (AM), kalium persulfat (KPS), penaut 
silang N,N-metilena bisakrilamida 99\% (BIS), natrium hidroksida $(\mathrm{NaOH})$ dan urea diperoleh daripada pembekal Sigma-Aldrich, larutan penimbal dan air suling.

\section{Penyediaan serbuk selulosa bakteria daripada nata de coco}

Penyediaan serbuk selulosa bakteria telah dilakukan mengikut kaedah yang dilaporkan oleh Halib et al. [6]. Nata de coco terlebih dahulu dibasuh dengan menggunakan air suling sebelum direndam dalam air suling yang telah dididihkan. Kemudian, natrium hidroksida akan dimasukkan dan dibiarkan semalaman dengan tujuan membolehkan sisa protein dalam nata de coco akan terlarut dalam air suling. Seterusnya, ianya dibasuh dengan menggunakan air untuk membuang sisa protein yang terlarut dalam air rendaman nata de coco. Proses diteruskan dengan merendamnya dalam air suling didih selama 2 jam sebelum dibasuh. Langkah ini diulangi sehingga nilai $\mathrm{pH}$ yang diperoleh adalah neutral. Nata de coco yang telah ditulenkan akan dikisar dengan menggunakan pengisar bahan basah sebelum dikeringkan dalam oven. Kepingan nata de coco yang telah kering dikisar dengan menggunakan pengisar kering untuk mendapatkan serbuk selulosa yang halus.

\section{Penyediaan hidrogel selulosa bakteria}

Penghasilan hidrogel terbiodegradasi di mana selulosa bakteria (BC) bertindak sebagai ko-monomer telah dilakukan dengan menggunakan kaedah yang digunakan oleh Pandey dan Amin [10]. Larutan selulosa bakteria (BC) disediakan dengan menyerakkan serbuk $\mathrm{BC}$ ke dalam $8 \%$ larutan $\mathrm{NaOH}$ dan $4 \%$ larutan urea. Sampel kemudiannya disimpan di dalam peti sejuk beku pada suhu $4{ }^{\circ} \mathrm{C}$ selama 24 jam. Larutan beku ini kemudiannya dikacau untuk menghasilkan larutan $\mathrm{BC}$ yang homogany.

Sebanyak $10 \mathrm{~mL}$ larutan selulosa bakteria dimasukkan ke dalam bikar bersama dengan pengacau bermagnet untuk proses pengacauan. Proses pengacauan ini dibiarkan selama 3 minit tanpa adanya proses pemanasan untuk memastikan larutan selulosa bakteria adalah homogen. Akrilamida (AM) kemudiannya ditimbang sebelum dicampurkan ke dalam larutan selulosa bakteria (BC). Berdasarkan kajian penyelidikan terdahulu [6,10] nisbah akrilamida yang dipilih dan digunakan dalam kajian ini adalah sebanyak 5\% (w/v) (hidrogel A) dan 10\% (w/v) (hidrogel B). Proses pengacauan diteruskan lagi setelah akrilamida dimasukkan. Setelah akrilamida larut sepenuhnya, kalium persulfat (KPS) dimasukkan ke dalam larutan BC di mana KPS bertindak sebagai bahan pemula cahaya. Nisbah berat KPS yang dimasukkan telah ditetapkan kepada 5\% daripada nisbah berat akrilamida yang digunakan. N,N-metilena bisakrilamida (BIS) kemudiannya dicampurkan setelah kalium persulfat telah larut sepenuhnya. Dalam kajian ini, BIS berfungsi sebagai agen pentaut silang. Nisbah berat BIS yang dicampurkan ke dalam larutan pula telah ditetapkan kepada 10\% daripada nisbah berat akrilamida yang digunakan.

Apabila kesemua bahan telah larut sepenuhnya, proses pengacauan dihentikan. Campuran tadi kemudiannya dimasukkan ke dalam piring petri kaca dan diradiasikan dengan menggunakan teknik radiasi ultra lembayung (instrumen UV kristal terawat model MKD-UV-800 Photo, USA) selama 360 saat. Hidrogel yang telah diradiasi kemudiannya dimasukkan ke dalam ketuhar pada suhu $40-45^{\circ} \mathrm{C}$ selama semalaman untuk proses pengeringan.

\section{Ujian pengembangan}

Ujian pengembangan hidrogel dilakukan dengan menggunakan larutan penimbal pada $\mathrm{pH}$ yang berbeza bertujuan untuk mengetahui kesan $\mathrm{pH}$ yang berlainan terhadap hidrogel. Oleh itu, lima larutan penimbal dengan nilai $\mathrm{pH} 3,5$, 7, 9 dan 12 telah disediakan. Hidrogel kemudiannya direndam di dalam larutan penimbal ini dan beratnya akan ditimbang pada setiap selang lima minit selama 1 jam. Ujian ini dijalankan pada suhu bilik dan sebarang perubahan diperhatikan. Nisbah pengembangan hidrogel dikira dengan menggunakan persamaan seperti berikut:

$$
\% S=M t-\text { MoMo } \times 100 \%
$$

di mana $M o(\mathrm{~g})$ adalah jisim asal hidrogel dan $M t(\mathrm{~g})$ adalah jisim hidrogel yang telah mengembang pada masa $\mathrm{t}$ (minit).

\section{Spektroskopi inframerah transformasi fourier}

Kajian ini telah menggunakan Jumlah Pantulan Teratenuat-Spektroskopi Inframerah Transformasi Fourier (Perkin Elmer, USA) sebagai salah satu analisis yang dijalankan terhadap hidrogel bakteria selulosa. Instrumen ini 


\section{Norhanisah \& Azwan: SINTESIS DAN PENCIRIAN HIDROGEL TERBIODEGRADASI BERASASKAN BAKTERIA SELULOSA MENGGUNAKAN TEKNIK RADIASI ULTRA LEMBAYUNG}

digunakan untuk mengenal pasti kumpulan berfungsi dalam hidrogel bakteria selulosa.

Analisis gravimetri termal-kalorimetri pengimbasan pembezaan

Analisis gravimetri termal adalah berdasarkan kepada ukuran perubahan jisim dalam keadaan sampel dipanaskan, disejukkan ataupun pada suhu malar. Selain daripada jisim sampel, TGA-DSC (Mettler Toledo, USA) juga boleh digunakan untuk mengukur aliran haba sampel. Hal ini membolehkan instrumen ini mengesan perubahan termal yang tidak melibatkan perubahan jisim seperti peleburan, peralihan kaca dan peralihan pepejal-pepejal. Malah, isyarat DSC juga boleh dinilai secara kuantitatif sekaligus membolehkan peralihan dan entalpi tindak balas ditentukan.

\section{Pembelauan sinar-X}

Analisis pembelauan sinar-X (D8 Advance, Bruker, USA), secara teorinya elektron dalam medan elektromagnet ulang-alik akan berayun pada frekuensi yang sama. Apabila alur sinar-X mengenai atom, elektron di sekitar atom akan mula berayun pada frekuensi yang sama dengan alur yang masuk.

\section{Mikroskopi pengimbasan elektron}

Mikroskopi pengimbasan elektron (JSM 5610, JEOL, USA) merupakan instrumen saintifik yang menggunakan alur elektron bertenaga tinggi untuk menentukan morfologi objek pada skala yang sangat kecil terutamanya dalam bidang biologi, perubatan dan sains bahan [11].

\section{Kesan pH ke atas peratus pengembangan hidrogel}

\section{Keputusan dan Perbincangan}

Peratus pengembangan tertinggi bagi kedua-dua hidrogel A dan hidrogel B pada setiap $\mathrm{pH}$ telah dicatatkan seperti dalam Jadual 1 di atas. Berdasarkan peratus pengembangan ini, graf perbandingan bagi kedua - dua hidrogel A dan B kemudiannya telah diplot seperti dalam Rajah 1.

Jadual 1. Perbandingan peratus pengembangan tertinggi bagi kedua-dua hidrogel untuk setiap nilai $\mathrm{pH}$

\begin{tabular}{lccc}
\hline \multirow{2}{*}{$\mathbf{p H}$} & \multicolumn{3}{c}{ Peratus Pengembangan Tertinggi Hidrogel (\%) } \\
\cline { 2 - 4 } & Hidrogel A & Hidrogel B & Perbezaan \\
\hline 3 & 520 & 300 & 220 \\
5 & 740 & 460 & 280 \\
7 & 710 & 490 & 220 \\
9 & 740 & 460 & 280 \\
12 & 840 & 570 & 270 \\
\hline
\end{tabular}

Merujuk kepada graf dalam Rajah 1, dapat dilihat berlakunya penurunan peratus pengembangan bagi kedua -dua hidrogel pada $\mathrm{pH}$ yang berbeza. Bagi hidrogel $\mathrm{A}$, peratus pengembangan hidrogel pada $\mathrm{pH} 3$ adalah $520 \%$ dan meningkat sehingga $740 \%$ pada $\mathrm{pH}$ 5. Namun, peratus pengembangan hidrogel ini telah menurun kepada $710 \%$ dalam larutan penimbal $\mathrm{pH}$ 7. Kemudian, peratus pengembangan hidrogel A kembali meningkat sehingga $740 \%$ pada $\mathrm{pH} 9$ dan seterusnya $840 \%$ pada $\mathrm{pH} 12$. Keputusan yang diperoleh adalah signifikan dengan keputusan yang pernah dilaporkan sebelum ini [12].

Bagi hidrogel B pula, peratus pengembangan tertinggi hidrogel pada $\mathrm{pH} 3$ adalah $300 \%$. Peratus pengembangan ini semakin meningkat pada $\mathrm{pH} 5$ dengan nilai peratus sebanyak $460 \%$ dan seterusnya $490 \%$ pada $\mathrm{pH} 9$. Walau bagaimanapun, peratus pengembangan hidrogel ini telah menurun sehingga $460 \%$ pada $\mathrm{pH} 9$ sebelum kembali meningkat pada $\mathrm{pH} 12$ dengan 570\%. Menerusi Jadual 1 dan Rajah 1, dapat dilihat hidrogel A iaitu hidrogel dengan nisbah AM kepada selulosa bakteria 5\% w/v mempunyai daya serapan yang lebih tinggi daripada hidrogel B dalam semua nilai $\mathrm{pH}$. Hal ini menunjukkan kadar pengembangan hidrogel A adalah lebih cepat berbanding dengan hidrogel B. 


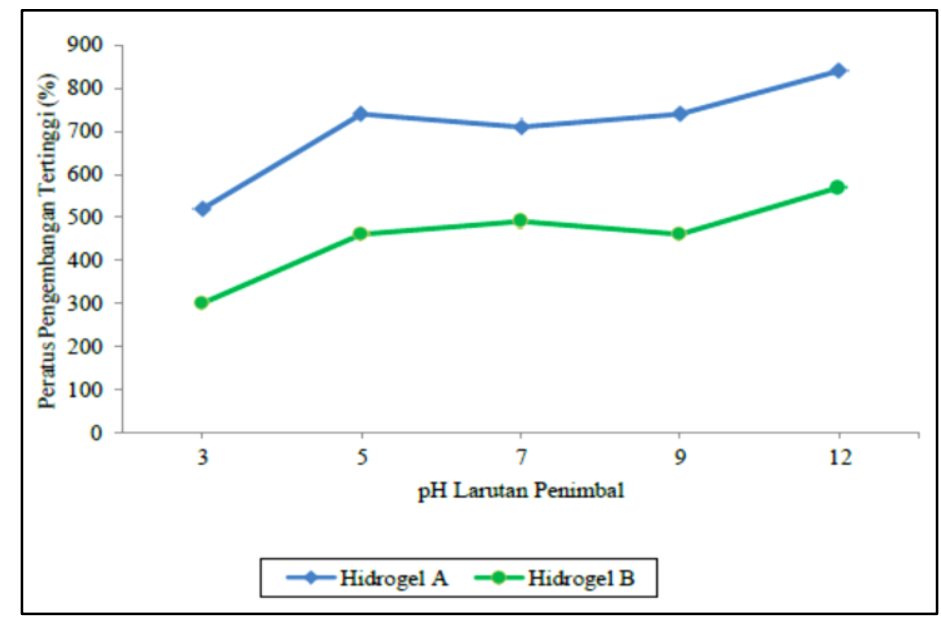

Rajah 1. Graf peratus pengembangan tertinggi (\%) terhadap $\mathrm{pH}$ bagi hidrogel A dan hidrogel B

Peratus pengembangan kedua-dua hidrogel A dan B yang tertinggi adalah pada larutan penimbal $\mathrm{pH} 12$. Hal ini kerana, larutan dengan nilai $\mathrm{pH}$ yang tinggi akan menyebabkan kumpulan $-\mathrm{CONH}_{2}$ dihidrolisiskan. Apabila kumpulan $-\mathrm{CONH}_{2}$ dihidrolisis, penolakan antara kumpulan karboksilat yang bercas akan berlaku sekaligus memanjangkan ikatan polimer. Hal ini akan mewujudkan ruang yang besar dalam hidrogel untuk menyerap air dan meningkatkan pengembangan hidrogel. Walau bagaimanapun, apabila hidrogel telah mencapai tahap serapan air yang maksima, ianya akan menyebabkan hidrogel tersebut menjadi rapuh dan mudah pecah.

Secara keseluruhannya, kedua-dua hidrogel menunjukkan kebolehan menyerap air yang baik. Nilai peratus pengembangan hidrogel yang paling minimum adalah $520 \%$ bagi hidrogel A manakala sebanyak $300 \%$ bagi hidrogel B. Berdasarkan Rajah 1, nilai peratus pengembangan paling minimum bagi kedua-dua hidrogel ini adalah pada $\mathrm{pH} 3$.

\section{Spektroskopi inframerah transformasi fourier}

Kajian berdasarkan Rajah 2 di atas, spektrum menunjukkan ketiga - tiga hidrogel mempunyai puncak utama yang hampir sama tetapi ketara berbeza dari segi keamatannya. Hal ini kerana interaksi yang berlaku antara jaringan selulosa bakteria dan akrilamida sewaktu pembentukan hidrogel bagi ketiga-tiga jenis hidrogel adalah sama.

Spektrum inframerah untuk kedua-dua hidrogel A dan B menunjukkan puncak keamatan masing-masing pada sekitar $3362 \mathrm{~cm}^{-1}$ dan $3343 \mathrm{~cm}^{-1}$ yang mewakili kumpulan $-\mathrm{OH}$ bagi selulosa yang mempunyai ikatan hidrogen. Selain itu, spektrum hidrogel B mempunyai puncak pada $2922 \mathrm{~cm}^{-1}$ yang menunjukkan kesan regangan $-\mathrm{CH}_{2}$ dari kumpulan $-\mathrm{CH}_{2} \mathrm{OH}$ yang terdapat dalam selulosa bakteria [6]. Manakala, puncak $1658 \mathrm{~cm}^{-1}$ bagi hidrogel A dan $1655 \mathrm{~cm}^{-1}$ bagi hidrogel $\mathrm{B}$ terhasil daripada getaran $\mathrm{C}=\mathrm{O}$ kumpulan $-\mathrm{CONH}_{2}$ yang terdapat dalam akrilamida.

Malah, pembentukan puncak $1658 \mathrm{~cm}^{-1}$ bagi hidrogel A dan $1655 \mathrm{~cm}^{-1}$ bagi hidrogel B telah menunjukkan bahawa berlakunya hidrolisis poliakrilamida yang membawa kepada penukaran kumpulan $-\mathrm{CONH}_{2}$ kepada $-\mathrm{COO}^{-}$[8]. Kedua-dua spektrum bagi hidrogel A dan B juga telah menunjukkan puncak keamatan pada julat $3500-3100 \mathrm{~cm}^{-1}$ yang mewakili kumpulan N-H dalam akrilamida. Getaran regangan C-O-C dalam ikatan eter selulosa bakteria pula ditunjukkan pada puncak $1165 \mathrm{~cm}^{-1}$ bagi hidrogel A dan $1159 \mathrm{~cm}^{-1}$ bagi hidrogel $\mathrm{B}$.

Jika dibandingkan dengan hidrogel $\mathrm{A}$ dan $\mathrm{B}$, spektrum bagi hidrogel akrilamida mempunyai puncak yang lebih tajam pada $1647 \mathrm{~cm}^{-1}$. Puncak yang terhasil ini adalah disebabkan oleh kehadiran kumpulan $\mathrm{C}=\mathrm{O}$ dalam ikatan bersama amida. Selain itu, puncak $2934 \mathrm{~cm}^{-1}$ pula menunjukkan kesan regangan $-\mathrm{CH}_{2}$ daripada kumpulan $-\mathrm{CH}_{2} \mathrm{OH}$. Malah turut dapat diperhatikan juga kehadiran kumpulan N-H dalam spektrum hidrogel akrilamida pada julat $3500-3100 \mathrm{~cm}^{-1}[13]$. 


\section{Norhanisah \& Azwan: SINTESIS DAN PENCIRIAN HIDROGEL TERBIODEGRADASI BERASASKAN BAKTERIA SELULOSA MENGGUNAKAN TEKNIK RADIASI ULTRA LEMBAYUNG}

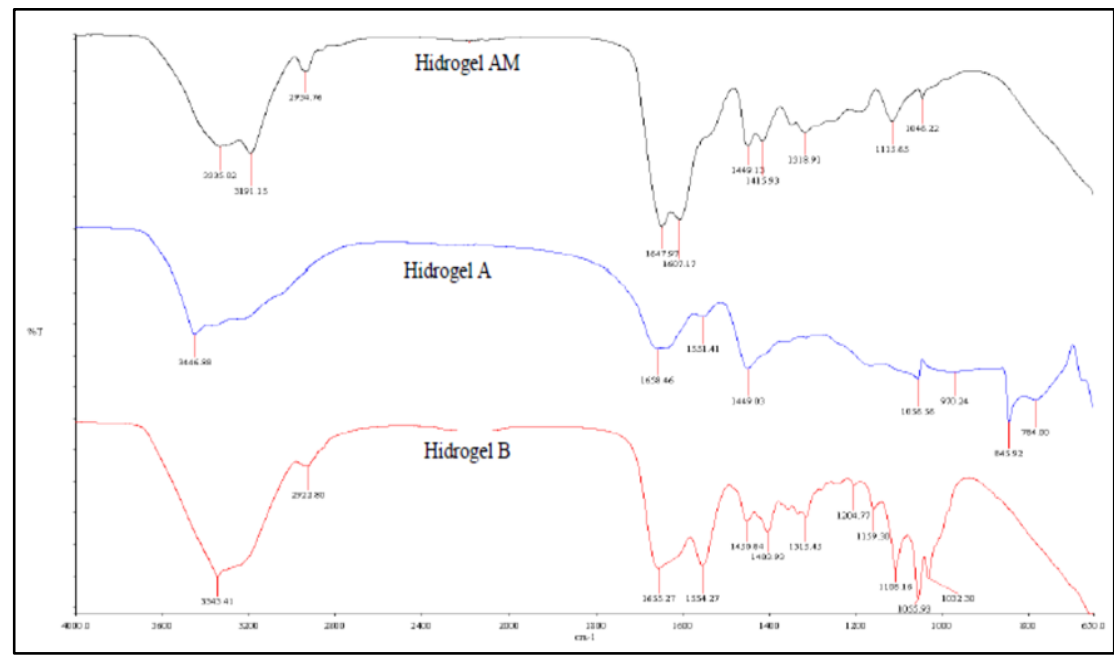

Rajah 2. Perbandingan spektrum inframerah bagi ketiga-tiga hidrogel di mana a) hidrogel AM b) hidrogel A dan c) hidrogel B

\section{Analisis gravimetri termal-kalorimetri pengimbasan pembezaan}

Analisis perbandingan keluk kalorimetri pengimbasan pembezaan dan analisis gravimetri termal (DSC/TGA) bagi hidrogel A dan B dapat dilihat seperti yang ditunjukkan dalam Rajah 3 di bawah. Berdasarkan keluk TGA, dapat dilihat bahawa kadar kehilangan berat maksimum bagi hidrogel A berlaku dalam julat suhu $150-200{ }^{\circ} \mathrm{C}$ manakala bagi hidrogel B pula berlaku dalam julat suhu $175-200{ }^{\circ} \mathrm{C}$. Pada julat suhu $475-600{ }^{\circ} \mathrm{C}$ pula, keluk kedua-dua hidrogel $\mathrm{A}$ dan $\mathrm{B}$ menunjukkan tiada kehilangan berat berlaku seiring dengan penurunan nilai peralihan menghampiri peleburan.

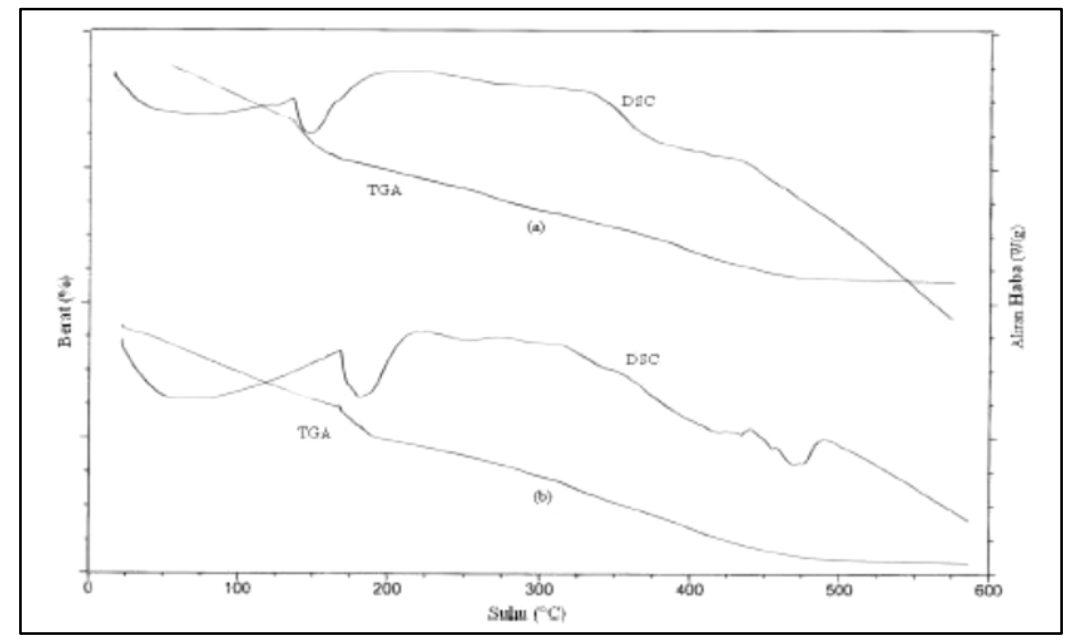

Rajah 3. Perbandingan keluk TGA-DSC bagi a) hidrogel B dan b) hidrogel A

Manakala, puncak yang terhasil pada keluk DSC bagi kedua-dua hidrogel berkemungkinan disebabkan oleh peralihan fasa yang berkaitan dengan pembentukan dan pemutusan jaringan selulosa bakteria [14]. Menurut Halib et al. [6], selulosa bakteria mempunyai banyak kumpulan hidroksil di mana kumpulan ini akan bertindak balas dengan air untuk membentuk ikatan hidrogen sekaligus membolehkan hidrogel selulosa bakteria mengembang. Berdasarkan 
keluk DSC, nilai peralihan kaca bagi hidrogel A berlaku dalam julat suhu $175-225^{\circ} \mathrm{C}$ manakala nilai peralihan kaca bagi hidrogel B berlaku dalam julat suhu $150-200{ }^{\circ} \mathrm{C}$. Hal ini menunjukkan bahawa hidrogel A mempunyai kestabilan terma yang lebih tinggi berbanding hidrogel B kerana peningkatan jumlah molekul air yang terikat pada selulosa bakteria akan meningkatkan nilai peralihan kaca. Perbandingan nilai peralihan kaca dan pengurangan berat maksimum bagi kedua-dua hidrogel dapat dilihat dengan lebih jelas seperti dalam Jadual 2 di bawah.

Jadual 2. Perbandingan termogram bagi kedua-dua hidrogel A dan B

\begin{tabular}{lcc}
\hline $\begin{array}{l}\text { Nilai pengurangan berat maksimum/ Nilai peralihan kaca }\left({ }^{\circ} \mathbf{C}\right) \\
\text { Nisbah hydrogel }\end{array}$ & TGA & DSC \\
\hline Hidrogel A & $150-200$ & $175-225$ \\
Hidrogel B & $175-200$ & $150-200$ \\
\hline
\end{tabular}

\section{Pembelauan sinar-X}

Dalam kajian ini, analisis pembelauan sinar-X telah digunakan untuk mencirikan peratusan penghabluran hidrogel berasaskan selulosa bakteria [15]. Rajah 4 telah menunjukkan perbandingan peratus penghabluran antara hidrogel akrilamida, hidrogel A dan juga hidrogel B.

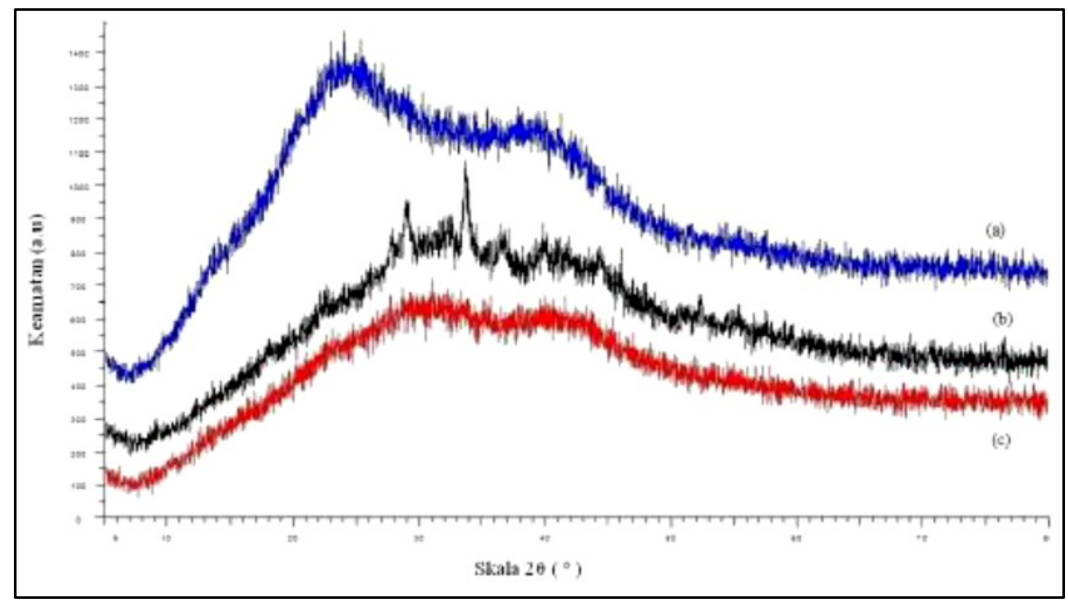

Rajah 4. Perbandingan peratus penghabluran di antara hidrogel a) hidrogel akrilamida, b) hidrogel A dan c) hidrogel B

Berdasarkan Rajah 4 di atas, spektrum menunjukkan puncak keamatan bagi hidrogel A adalah hampir sama seperti hidrogel B. Tetapi, hidrogel A mempunyai beberapa puncak puncak yang lebih tinggi dan tajam jika dibandingkan dengan puncak bagi hidrogel B yang kelihatan lebih luas. Puncak keamatan hidrogel B yang lebar dan luas menunjukkan bahawa hidrogel ini mengandungi lebih banyak komponen amorfus. Manakala, puncak keamatan hidrogel A yang lebih tajam pula menunjukkan peratus penghabluran bagi hidrogel A adalah lebih tinggi berbanding dengan hidrogel $\mathrm{B}$.

Rajah 4 juga menunjukkan hidrogel akrilamida mempunyai puncak yang lebih tinggi dan kurang lebar berbanding dengan hidrogel A dan juga hidrogel B. Hal ini menunjukkan peratus penghabluran bagi hidrogel akrilamida adalah lebih tinggi. Walau bagaimanapun, peratus penghabluran yang terlalu tinggi boleh mendorong kepada peningkatan kadar kerapuhan hidrogel [16].

Mikroskopi pengimbasan elektron

Dalam kajian ini, analisis mikroskopi pengimbasan elektron (SEM) telah digunakan untuk membandingkan 


\section{Norhanisah \& Azwan: SINTESIS DAN PENCIRIAN HIDROGEL TERBIODEGRADASI BERASASKAN BAKTERIA SELULOSA MENGGUNAKAN TEKNIK RADIASI ULTRA LEMBAYUNG}

morfologi permukaan antara hidrogel A dan juga hidrogel B. Berdasarkan Rajah 5, morfologi permukaan kedua dua hidrogel menunjukkan wujudnya liang - liang terbuka dalam hidrogel. Kewujudan liang - liang ini membolehkan proses penyerapan air berlaku dari semua arah sekaligus dapat menentukan tahap keporosan hidrogel [12].
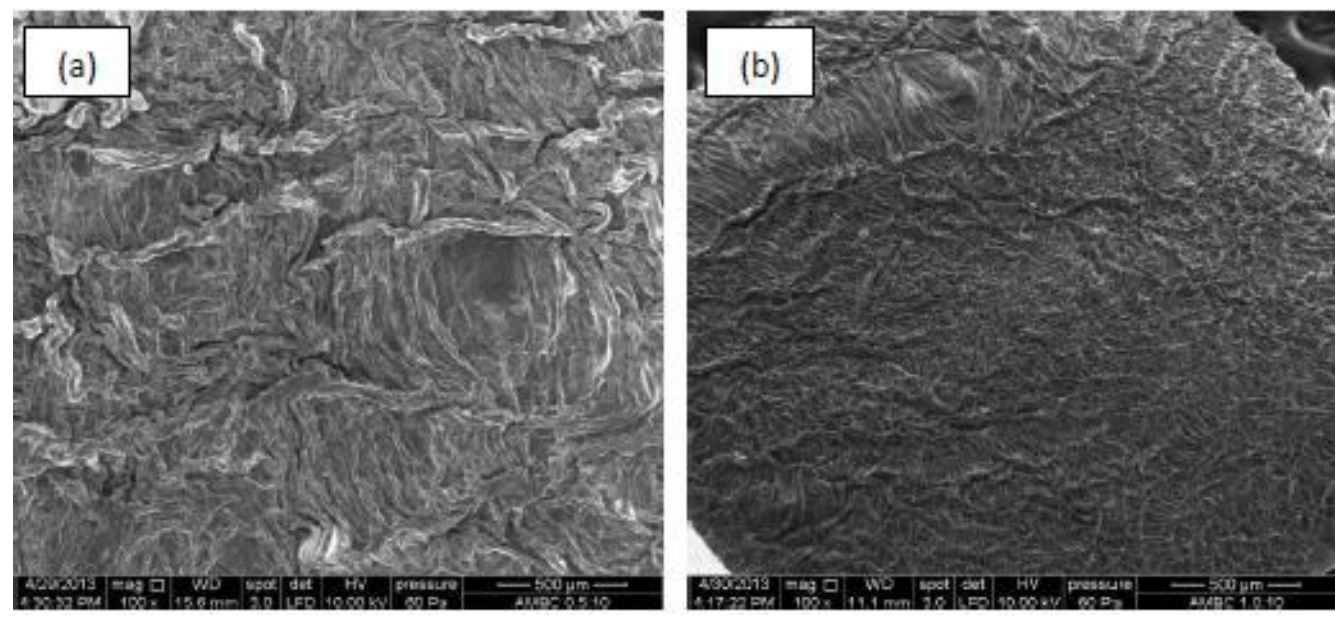

Rajah 5. Mikrograf SEM bagi hidrogel berasaskan selulosa di mana a) hidrogel A dan b) hidrogel B

Berdasarkan ujian pengembangan, didapati hidrogel A mempunyai nilai peratus pengembangan yang lebih tinggi berbanding hidrogel $\mathrm{B}$. Hal ini kerana hidrogel A mempunyai tahap keporosan yang lebih tinggi memandangkan liang - liang yang terdapat dalam hidrogel A adalah lebih banyak dan besar daripada hidrogel B.

\section{Kesimpulan}

Hidrogel berasaskan selulosa boleh diketengahkan sebagai bahan bio untuk diaplikasikan dalam pelbagai bidang seperti kejuruteraan tisu, penghantaran ubat dan komponen elektronik. Berdasarkan kajian yang telah dan sedang dijalankan, hidrogel berasaskan selulosa bakteria telah berjaya dihasilkan dengan menggunakan teknik ultra lembayung terawat. Teknik telah menghasilkan sampel hidrogel berasaskan selulosa bakteria bagi dengan ciri-ciri yang setara dengan sampel yang dihasilkan menggunakan sinar gamma dan sinar alur elektron (EB). Malah teknik ini menawarkan satu kaedah yang murah dan mudah sebagai alternatif kaedah konvensional dan teknik radiasi yang lain.

\section{Rujukan}

1. Schacht, E. H. (2004). Polymer chemistry and hydrogel systems. Journal of Physics: Conference Series, 3: 22 28.

2. Hoffman A. S. (2002). Hydrogels for biomedical applications. Advanced Drug Delivery Reviews, 43: 3 - 12.

3. Langer, R. and Peppas, N. A. (2003). Advances in biomaterials, drug delivery, and bionanotechnology. Bioengineering, Food, And Natural Products, 49(2003): 2990 - 3006.

4. Brown, R. M., Jr. (2004). Cellulose structure and biosynthesis: What is on the store for the $21^{\text {st }}$ Century? Journal of Polymer Science: Part A: Polymer Chemistry, 42(3): 487 - 495

5. Sannino, A., Demitri, C. and Madaghiele, M. (2009). A review on biodegradable cellulose-based hydrogels: Design and applications. Materials, 2(2009): $353-373$.

6. Halib, N., Amin, M. C. I. M. and Ahmad, I. (2012). Physicochemical properties and characterization of nata de coco from local food industries as a source of cellulose. Sains Malaysiana, 41(2): $205-211$.

7. Azman, I., Mutalib, S. A., Yusoff, S. F. M., Fazry, S., Noordin, A., Kumaran, M. and Lazim, A. M. (2016). Novel dioscorea hispida starch-based hydrogels and their beneficial use as disinfectants. Journal of Bioactive and Compatible Polymers, 31(1): $42-59$. 
8. Amin, M. C. I. M., Abadi, A. G., Ahmad, N., Katas, H. and Jamal, J. A. (2012). Bacterial cellulose film coating as drug delivery system: Physicochemical, thermal and drug release properties. Sains Malaysiana, 41(5): $561-$ 568.

9. Amin, M. C. I. M., Ahmad, N., Halib, N. and Ahmad, I. (2012). Synthesis and characterization of thermo- and pH-responsive bacterial cellulose/acrylic acid hydrogels for drug delivery. Carbohydrate Polymers, 88(2): 465 $-473$.

10. Pandey, M. and Amin, M. C. I. M. (2012). Accelerated preparation of novel bacteria cellulose/acrylamidebased hydrogel by microwave irradiation. International Journal of Polymeric Materials, 62: $402-405$.

11. Voutou, B. and Stefanaki, E. C. (2008). Electron microscopy: The basics. Physics of Advanced Materials Winter School, 2008: pp. $1-11$.

12. Halib, N., Amin, M. C. I. M. and Ahmad, I. (2010). Unique stimuli responsive characteristics of electron beam synthesized bacterial cellulose/acrylic acid composite. Journal of Applied Polymer Science, 116: 2920 - 2929.

13. Lampman, G. M., Pavia, D. L., Kriz, G. S. and Vyvyan, J. R. (2010). Introduction to Spectroscopy. United States of America: Brooks/Cole Cengage Learning.

14. Jager, H. J. and Prinsloo, L. C. (2001). The dehydration of phosphates monitored by DSC/TGA and in situ Raman spectroscopy. Thermochimica Acta, 376: 187 - 196.

15. Prevey, P. S. (2009). X-ray diffraction characterization of crystallinity and phase composition in plasmasprayed hydroxylapatite coatings. Journal of Thermal Spray Technology, 9(3): 369 - 376.

16. Scintag Inc. (1999). Chapter 7: Basic of X-ray diffraction. www.scintag.com [Access online 10 Mei 2013]. 